Przegląd Badań Edukacyjnych Educational Studies Review

ISSN 1895-4308

nr $32(1 / 2021)$, s. 179-192
ORYGINALNE ARTYKULY BADAWCZE

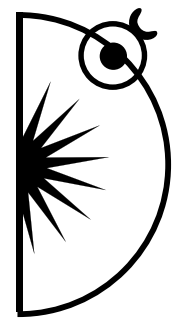

Miłosz Wawrzyniec Romaniuk

ORCID: https://orcid.org/0000-0002-1009-8940

The Maria Grzegorzewska University, Warsaw, Poland;

e-mail:mromaniuk@aps.edu.pl

\title{
The Role of Sail Training as a Factor Strengthening the Hardiness of Extraordinary Youth
}

http://dx.doi.org/10.12775/PBE.2021.010

\begin{abstract}
The paper presents the results of research on the level of the hardiness of participants of high sea cruises implementing the idea of sail training and being a non-standard form of informal education in practice. The study involved 123 people, including 65 girls and 58 boys aged 13 to 18 years, who can be perceived as youth with special educational needs. They were participants of the Krzysztof Baranowski School Under Sails in 2015 and 2016, the cruise of the 42 Author's High School in Warsaw from 2016, the Catholic School Under Sails in 2017 and Gdańsk School Under Sails in 2019.

Method: Pre-posttest study with questionnaires issued on the first and last day of each cruise. Dispositional Resilience Scale was used to measure mental hardiness, commitment, openness to challenges and a sense of control of participants. T-tests were used to check the significance of change in results.

Results: The results show a statistically significant increase in hardiness level measured using the Dispositional Resilience Scale. There was also a significant increase in commitment, openness to challenges and a sense of control of participants, which are measured by subscales of the used scale.

Conclusions: It can be thought that various types of Schools under Sail are an attractive way to adapt to the special educational needs of gifted young people and strengthen the hardiness of young people, which is a valuable asset of sail training.
\end{abstract}

Keywords: sail training, School Under Sails, hardiness, special educational needs, extraordinary youth. 


\section{Introduction}

High sea sailing is a very demanding discipline. A sailor should not only have substantive knowledge, practical skills or be physically fit, but should present specific psychological predispositions. During a sea voyage, a man faces the element of the sea, and struggles with wind, water, ship and travel companions. However, he fights the most demanding struggle with himself. Taking up the fight against your own weaknesses is conditioned by the feeling that you are able to deal with them (Romaniuk, 2018).

Young people deciding to take part in a high seas cruise indicate that their most important motivation is their willingness to test themselves in difficult conditions (Romaniuk \& Łukasiewicz-Wieleba, 2019). Undertaking such activities is an essential factor in the process of shaping your identity and achieving the development goals of the adolescence period (Romaniuk, 2015). Challenges with such a high degree of difficulty are mainly taken up by young people with a positive attitude towards themselves (Romanowska-Tołłoczko \& Piwowarczyk, 2015).

Young people deciding to take part in a high seas School Under Sails cruise are exceptional and unique because they take the challenge to take part in a difficult and long-term recruitment process, voluntarily decide on all duties and discomforts arising from work and life on board of a sailing ship and are actively looking for additional, non-school forms of development and education. They are young people showing transgression, which characterizes people with outstanding creative abilities (Kozielecki, 1986). The synergy of transgressive behavior and creative competencies ensures efficiency, unconventionality and effectiveness of undertaken actions, which means that a person actively and intentionally undertakes creative activity, develops and creatively changes the space around him, because he can break the framework of schematic behavior (Kozielecki, 1987). Sail training creates an excellent environment for the development of abilities, by enabling effective interaction of the triad of intellectual abilities of young people, their directional talents and motivations that are integrated through personality (Renzulli, 1977) and ship reality. The social environment and climate onboard the ship is a key factor in catalyzing the development of youth traits and personality (Heller et al., 2000). A proactive attitude, determination and successful completion of recruitment, and later creative facing challenges encountered during the cruise are indicators of the psychophysical capabilities of a young person, which are part of the canon of the characteristics of an extraordinary person, specially gifted, as well as having special educational, and developmental needs. 
The idea of sail training is education and upbringing of youth through the sea, work and study onboard of a seagoing sailing vessel. Sail training in a pedagogical scope is a process that in an organized and purposeful way influences the personality, attitudes, characteristics, and hierarchy of values of its participants, shaping the character and social competences, affecting participants in every sphere (physical, mental, spiritual, social, cultural) in a socially desirable way that takes place on board of a sailing vessel during a high seas voyage, based on the participants' contact with the element of the sea, through which transgression and a developmental leap occur, which is a life-changing experience. Entities organizing cruises like School Under Sails want to have a lasting, positive impact on the comprehensive development and shaping the character of young people. They want to educate young people through experience, teach social competences and transfer substantive knowledge not only connected with sailing, but also with what is in the core curriculum for schools. The youth, as a full-fledged crew, with their work, causes the ship to sail, keep it tidy and in good technical condition by keeping navigational, galley and bosun watches. In addition, young people take part in educational activities. Sail training can be a life changing experience (Romaniuk, 2020c), that elevates self-esteem (Romaniuk, 2020b), and self-efficacy (Romaniuk, 2020a).

\section{Theoretical approach to hardiness}

Hardiness is a source of immunity when dealing with a stressful situation. It alleviates the consequences of stress and keeps mental and physical health. Hardiness is a combination of three features: commitment, sense of control and openness to challenges. Their synergy transforms the perception of difficult situations from potential threats into development opportunities (Maddi, 2002). Hardiness is a way of functioning at the cognitive, behavioral, emotional and personality levels, which includes dealing with problems and the individual's approach to life (Bartone, 2012). A mentally hard person has the belief that he can control or influence events in which he participates, has the ability to devote himself deeply to purposeful life activities and anticipates change as exciting challenges enabling his own development (Kobasa, 1979). Commitment is expressed in taking on challenges with perseverance and confidence, which do not diminish in the face of adversity. Commitment is also a stubborn pursuit of success, seeing the sense of your actions, future orientation, optimism and the ability to learn from your past experiences wi- 
thout thinking about failures. A sense of control is a belief in the real impact of one's own actions on the course of events and a sense of agency. The sense of control allows us to make autonomous decisions, see various options for action and efficiently adapt them to the situation and the taken action plan. Stress coping strategies are diverse and available for such people to be effectively used even in difficult situations. The regulation of one's own behavior is conditioned by a sense of causativeness and self-efficacy (Bandura \& Walters, 1977). Openness to challenges is expressed by accepting the changeability of reality, the ability to adapt to it and perceive it as a stimulus for development. Mentally hard people see difficulties as opportunities, not obstacles (Maddi, 2006).

Mental hardiness is also important for students: it correlates negatively with the level of exam anxiety and positively with school achievements (Khalatbari et al., 2013). People with high hardiness are less likely to suffer from mental disorders (Mostafei, 2012). They are healthier, less fearful and better control their emotions (Sajadi et al., 2012). They are less likely to have interpersonal problems, deal better with stress and have a higher level of well-being (Nathawat et al., 2010). Hardiness is a negative predictor of the declared level of disease (Kobasa et al., 1982), a positive predictor of the level of life activity in old age (Magnani, 1990), positive predictor of quality of life for people suffering from serious illnesses (Pollock, 1989), and a positive predictor of performance (Maddi \& Hess, 1992). Mentally hard people perceive changing life situations as less stressful (Allred \& Smith, 1989), are more effective in dealing with difficult situations (Maddi, 1999), are mentally healthier (Maddi et al., 2002), they present more innovative behaviors (Maddi et al., 2006), they are less prone to depression, anxiety and hostility, and more positive towards learning and development (Maddi et al., 2009) and more willing to search for meaning in experienced things (Maddi et al., 2011). These features are among those whose development is the goal of sail training. Developing them by strengthening the hardiness of young people is therefore desirable. The reason for taking up this subject was the desire to determine the relationship between sea voyages that implement the idea of sail training, in which school students participate and a change in the level of the hardiness of the participants.

\section{Research methodology and participants}

In the following study, it was hypothesized that participants of sea voyages who are subjects of sail training become mentally harder after a voyage, an increase 
in hardiness does not depend on the sex of the participant, and a positive effect in the form of an increase in hardiness can only be obtained during a voyage that meets the objectives of sail training and for which you have to qualify, and it's not just a yacht trip that anyone can take part in.

The study involved 143 people, including 75 girls (52.4\%) and 68 boys (47.6\%) aged 13 to 18 years from Poland. They took part in one of five cruises - the Krzysztof Baranowski School Under Sails on the STS Pogoria in 2015 (SpŻ, 2015), the Krzysztof Baranowski School Under Sails on the STS Pogoria in 2016 (SpŻ, 2016), the cruise of 42 Authors High School in Warsaw on four sailing yachts with a length of about 14 meters (ALON 42), the cruise of the Catholic School Under Sails in 2017 on the STS Pogoria (KSpŻ, 2017) and the cruise of the Gdańsk School Under Sails on the sailing ship STS General Zaruski (GSpŻ, 2019).

Differences in the length and route of the voyage and the type of ship on which they took place could have influenced the experience of the respondents. Participation in the research was voluntary, the anonymity of respondents was maintained. The sample consisted of cruise participants who, depending on the organizer, had to meet the cruise qualification requirements. In the case of School Under Sails on STS Pogoria, the participants had to show a specified number of volunteering hours and take part in a physical fitness test consisting of running, swimming and pulling up on a bar. In the case of the ALON42 cruise, the student's participation was decided by the order of applications and the school headmaster, taking into account the candidate's school achievements. The participant's qualification for the GSpŻ cruise was determined by the result of the competition which included a covering letter and a presentation of each pretender.

The respondents were surveyed using individual questionnaires. A 30-element Dispositional Resilience Scale (Cronbach's alpha $=0.82$ ) was used, which consists of three subscales measuring commitment, sense of control and openness to challenges (Bartone et al., 1989). During the first measurement, the respondents provided answers on the bus, on the way to the port or on the first day of the voyage, already on-board. The second measurement was carried out on the last day of the voyage still onboard the ship or on the bus, on the way back. 


\section{The results}

Data analysis was carried out in the program Statistical Package for Social Sciences (SPSS) 25.

Table 1. Descriptive statistics for the examined group $(\mathrm{N}=143)$.

\begin{tabular}{|l|c|c|}
\hline \multicolumn{1}{|c|}{ Measured construct } & M & SD \\
\hline Commitment before & 19.66 & 4.33 \\
\hline Commitment after & 20.66 & 4.34 \\
\hline Control before & 19.06 & 3.39 \\
\hline Control after & 19.71 & 4.00 \\
\hline Challenges before & 17.85 & 4.41 \\
\hline Challenges after & 18.92 & 3.39 \\
\hline Hardiness before & 56.57 & 8.40 \\
\hline Hardiness after & 59.29 & 8.93 \\
\hline
\end{tabular}

Source: Author's research.

The differences between the means were checked by the Student's t test for dependent samples. The results show a statistically significant increase in hardiness $(\mathrm{t}(142)=-4.685, \mathrm{p}<.001$, Cohen's $\mathrm{d}=.39$, Pearson's $\mathrm{r}=.68)$, commitment $(\mathrm{t}(142)=-3.766, \mathrm{p}<.001$, Cohen's $\mathrm{d}=.31$, Pearson's $r=.73)$, control $(\mathrm{t}(142)=-2.133$, $\mathrm{p}<.035$, Cohen's $\mathrm{d}=.17$, Pearson's $\mathrm{r}=.52)$ and openness $(\mathrm{t}(142)=-2.895, \mathrm{p}<.004$, Cohen's $\mathrm{d}=.24$, Pearson's $r=.38$ ).

Table 2. Descriptive statistics by gender ( $\mathrm{N}$ girls $=75, \mathrm{~N}$ boys $=68$ ).

\begin{tabular}{|l|c|c|c|c|}
\hline \multirow{2}{*}{\multicolumn{1}{|c|}{ Measured construct }} & \multicolumn{2}{c|}{ Girls } & \multicolumn{2}{c|}{ Boys } \\
\cline { 2 - 5 } & M & SD & M & SD \\
\hline Commitment before & 19.81 & 4.37 & 19.49 & 4.31 \\
\hline Commitment after & 20.68 & 4.43 & 20.63 & 4.27 \\
\hline Control before & 18.68 & 3.57 & 19.49 & 3.15 \\
\hline Control after & 19.43 & 4.06 & 20.03 & 3.94 \\
\hline Challenges before & 17.77 & 3.27 & 17.93 & 5.43 \\
\hline Challenges after & 18.99 & 3.33 & 18.84 & 3.48 \\
\hline Hardiness before & 56.27 & 8.85 & 56.90 & 7.93 \\
\hline Hardiness after & 59.09 & 9.12 & 59.50 & 8.78 \\
\hline
\end{tabular}

Source: Author's research. 
By gender, a statistically significant increase in hardiness level is noticeable in girls group ( $\mathrm{t}(74)=-3.487, \mathrm{p}<.001$, Cohen's $\mathrm{d}=.40$, Pearson's $\mathrm{r}=.70$ ), commitment $(\mathrm{t}(74)=-2.353, \mathrm{p}<.021$, Cohen's $\mathrm{d}=.21$, Pearson's $\mathrm{r}=.74)$ and openness $(\mathrm{t}(74)=-3.163, \mathrm{p}<.002$, Cohen's $\mathrm{d}=.37$, Pearson's $\mathrm{r}=.49)$. Change in control $(\mathrm{t}(74)=-1.844, \mathrm{p}<.069$, Cohen's $\mathrm{d}=.21$, Pearson's $\mathrm{r}=.58)$ is at the level of statistical trend. A statistically significant increase in hardiness level is noticeable in boys group ( $\mathrm{t}(67)=-3.107, \mathrm{p}<.003$, Cohen's $\mathrm{d}=.38$, Pearson's $\mathrm{r}=.66)$ and commitment $(\mathrm{t}(67)=-2.997, \mathrm{p}<.004$, Cohen's $\mathrm{d}=.36$, Pearson's $\mathrm{r}=.73)$. Changes in the sense of control and openness to challenges in boys group are not statistically significant.

Table 3. Descriptive statistics by cruises.

\begin{tabular}{|l|c|c|c|c|c|c|c|c|c|c|}
\hline \multirow{2}{*}{ Measured construct } & \multicolumn{2}{|c|}{ Spż 2015 } & \multicolumn{2}{c|}{ Spż 2016 } & \multicolumn{2}{c|}{ ALON 42 } & \multicolumn{2}{c|}{ KSpŻ 2017 } & \multicolumn{2}{c|}{ GSpż 2019} \\
\cline { 2 - 12 } & $\mathrm{M}$ & SD & $\mathrm{M}$ & SD & M & SD & M & SD & M & SD \\
\hline Commitment before & 19.85 & 3.60 & 20.83 & 4.11 & 18.42 & 4.57 & 19.32 & 5.33 & 20.11 & 3.38 \\
\hline Commitment after & 21.33 & 3.63 & 20.79 & 4.33 & 19.00 & 4.15 & 20.68 & 4.87 & 21.95 & 4.53 \\
\hline Control before & 20.15 & 3.61 & 18.69 & 3.23 & 18.58 & 3.19 & 18.71 & 3.24 & 19.11 & 3.70 \\
\hline Control after & 19.67 & 4.38 & 20.41 & 2.69 & 18.90 & 3.49 & 19.35 & 4.5 & 20.63 & 5.38 \\
\hline Challenges before & 17.39 & 3.33 & 17.34 & 3.02 & 18.29 & 7.35 & 17.71 & 3.29 & 18.89 & 3.05 \\
\hline Challenges after & 18.91 & 3.07 & 18.45 & 2.67 & 17.94 & 3.49 & 19.06 & 4.08 & 21.00 & 2.87 \\
\hline Hardiness before & 57.39 & 7.12 & 56.86 & 7.59 & 55.29 & 9.88 & 55.74 & 9.35 & 58.11 & 7.78 \\
\hline Hardiness after & 59.91 & 7.48 & 59.66 & 6.45 & 55.84 & 8.56 & 59.10 & 11.27 & 63.58 & 9.44 \\
\hline
\end{tabular}

Source: Author's research.

By cruise, the least effective is ALON 42, where there are no significant differences between measurements. This may be due to the short duration of the voyage, the large interference of teachers in student activities, mild weather conditions, and the lack of longer sailing between ports. A statistically significant increase in hardiness level is noticeable in the SpŻ 2015 cruise $(\mathrm{t}(32)=-2.166$, $\mathrm{p}<.038$, Cohen's $\mathrm{d}=.38$, Pearson's $\mathrm{r}=.58$ ), commitment level $(\mathrm{t}(32)=-2.757$, $\mathrm{p}<.010$, Cohen's $\mathrm{d}=.48$, Pearson's $\mathrm{r}=.63)$ and challenges level $(\mathrm{t}(32)=-2.669$, $\mathrm{p}<.012$, Cohen's $\mathrm{d}=.46$, Pearson's $\mathrm{r}=.48$ ). A statistically significant increase in hardiness level is noticeable in the SPŻ 2016 cruise $(\mathrm{t}(28)=-2.679, \mathrm{p}<.012$, Cohen's d $=.50$, Pearson's $\mathrm{r}=.69)$, control level $(\mathrm{t}(28)=-3.839, \mathrm{p}<.001$, Cohen's $\mathrm{d}=.71$, Pearson's $\mathrm{r}=.68)$ and challenges level $(\mathrm{t}(28)=-2.070, \mathrm{p}<.048$, Cohen's $\mathrm{d}=.38$, Pearson's $\mathrm{r}=.50$ ). A statistically significant increase in hardiness level is noticeable in the KSpŻ 2017 cruise $(\mathrm{t}(30)=-2.731, \mathrm{p}<.010$, Cohen's $\mathrm{d}=.49$, 
Pearson's $\mathrm{r}=.80)$ and commitment level $(\mathrm{t}(30)=-2.133, \mathrm{p}<.041$, Cohen's $\mathrm{d}=.38$, Pearson's r $=.76$ ). The increase in openness to challenges is at the level of statistical trend $(\mathrm{t}(30)=-2.004, \mathrm{p}<.054$, Cohen's $\mathrm{d}=.36$, Pearson's $\mathrm{r}=.50)$. In the GSpŻ 2019 cruise, the results show a statistically significant increase in hardiness level ( $\mathrm{t}(18)=-3.623, \mathrm{p}<.002$, Cohen's $\mathrm{d}=.83$, Pearson's $\mathrm{r}=.72$ ), commitment level $(\mathrm{t}(18)=-2.689, \mathrm{p}<.015$, Cohen's $\mathrm{d}=.62$, Pearson's $\mathrm{r}=.75)$ challenges level $(\mathrm{t}(18)=-3.099, \mathrm{p}<.006$, Cohen's d=.71, Pearson's $\mathrm{r}=.50)$.

\section{Conclusions and discussion of results}

The obtained results mean that the participants of sea voyages who are subjects of sail training recognized as a whole group are significantly more committed after the voyage, open to challenges, have a higher sense of control and are mentally harder than before the voyage.

There are noticeable differences between the formula of cruises. Cruises carried out on STS Pogoria and STS General Zaruski sailing ships bring better results in terms of increasing the level of the hardiness of the participants. The ALON 42 cruise took place on sailing yachts with a length of about 15 meters and lasted 14 days. Cruise crew participated in educational classes in ports, but navigation was limited to short, maximum one-day sailing, and work on the ship was limited to steering and preparing meals. The weather conditions during the cruise were mild and the place of sailing not very difficult (Balearic Sea), so the crew had no practical opportunity to test themselves in difficult conditions. It can be concluded that a trip of this type, which is more recreational than educational, is not a factor strengthening the hardiness of young people.

Cruises on traditional sailing ships, where young people are keeping navigational, galley and gangway watch, the young crew cleans the ship every day, helps in technical and maintenance work, has educational classes during sailing and where sailing between ports lasts longer (a couple of days) are a factor significantly strengthening the hardiness of young people. The obtained results indicate that the strongest effects were achieved during the three-week cruise on the STS General Zaruski. This may be due to differences in the cruise formula. Youth at STS General Zaruski has the greatest freedom of action left but also fulfills most of the duties on their own. Crew members are treated like adults and, most likely because they live, eat and learn in a common forecastle, develop the closest relationship between one another resolving conflicts by themselves and supporting one another. The staff interferes in the last resort and plays only a supporting role. At STS Pogoria, despite similar responsibili- 
ties, the model of youth work is different. The command is more direct, and young people do not have many opportunities to act independently. There are no grounds to claim that the length of the voyage significantly differentiates the results obtained (SPŻ voyages lasted two months, and KSpŻ a month), but further tests should be carried out to check if there is a voyage length limit below which the effect of increased hardiness level does not occur. For now, based on the GSpŻ cruise, it can be assumed that three weeks on a sailing ship is the minimum length of the cruise. Among the cruises to STS Pogoria, the least effective in terms of hardiness level was brought by the KSpŻ cruise, which may be due to the cruise formula focused on the spiritual and religious development of young people. The formula of the cruise seems to be an important factor, because it makes the youth, who come to participate in the cruise, tuned in differently so they start perceiving the cruise as a pleasure or an opportunity for development. Of course, these two approaches are not mutually exclusive, but they can properly direct the actions of young people and influence their behavior during the cruise.

After the cruise, girls are more committed, open to challenges and mentally harder than before the cruise, and their sense of control increases (at the level of statistical trend). The boys are more committed and mentally harder after the cruise than before. However, if the ALON 42 cruise was not taken into account, the differences in the boys' openness to challenges also become statistically significant $(\mathrm{t}(50)=-3,385, \mathrm{p}<.001$, Cohen's $\mathrm{d}=0.47$, Pearson's $\mathrm{r}=0.58)$. This confirms the earlier hypothesis about the importance of the factor, which is the cruise formula. Similarities in the increase of indicators of studied traits in boys and girls indicate that sail training is universal, and its positive impact is visible in participants regardless of gender.

Observation of participants during the voyage allows us to recognize that several components contributed to the increase in hardiness level. During doing their duties towards the ship, including keeping it tidy or performing minor technical work, the young got to know the ship and soon after embarking, they began to treat it as their home. Observing the bosun, who took care of the ship while doing his work, the participants also wanted to take part in the onboard work. They began to get more involved and committed, and, after a few days, learned to use mechanical tools such as a grinder, heat gun or jigsaw, mastered simple weaves or knots on ropes, as well as learned to varnish, oil, paint and maintain parts of the ship. They started with simple tasks carried out under the supervision of a permanent crew (captain, bosun, mates), and, as time went by, learned to master new things and raised their competencies related to manual 
work. The example of diligence, solidarity and openness gave by the permanent crew was a motivating element from which the activity of young people began. Dealing with the ship and observing the permanent crew are factors that may underlie the increase in youth commitment. The modeling effect meant that the crew wanted to develop themselves. It was strengthened when the youth noticed that they are able to master technical skills, social competences and substantive knowledge useful on the ship but also in everyday life. Awareness of the possibility of dealing with new things is an element that most likely influenced the increase in the level of openness to challenges in young people. It should be emphasized that before the cruise, few crew members operated this type of tool and performed such technical work, or co-existed in a closed micro-community in a small space.

The increase in the level of sense of control is visible to the group of participants as a whole. Young people on a ship sailing on the high seas may at first feel dependent on the actions of the permanent crew or weather conditions. During acquiring sailing competences, they note that the weather can be forecast, and they have an influence on the preparation of the ship and themselves to more difficult conditions. When working with sails, they see that it is their actions that cause the ship to sail in the right direction, they understand that they have a real impact on sailing and navigation. In their role as senior of the watch (mate's assistant), they can make autonomous decisions regarding the performance of their duties and adjust their strategy to the situation. The effect may not be the greatest, due to the fact that even if the youth are left with a lot of freedom of action and a field to make decisions, the captain commands the ship and has the last word, and the mates manage the watch, and their opinion is binding on the youth. Nevertheless, it is noticeable and worth emphasizing.

The participants' hardiness could develop as a result of struggling with their weaknesses during the cruise. Participants indicate the fight against seasickness during rocking, drowsiness during night watches, cold during windy and rainy watches, fear and anxiety in moments of stronger wind and greater waves or against fatigue during the whole day of galley watch as the biggest challenges related to sailing (Romaniuk, 2015). Awareness of facing adversities, overcoming their weaknesses and crossing the boundaries of their comfort zone allowed young people to cope with the situation of testing themselves and contributed to an increase in the level of hardiness.

An increase in the level of hardiness in combination with other values internalized by young people during sail training is a positive and desirable effect. Research has shown the usefulness of conducting mental hardiness training 
(Maddi \& Khoshaba, 2003), and in particular the need to support students with special educational needs in this matter (Shchipanova et al., 2016). It becomes a personality trait supporting the functioning and strength of the ego by confronting changes, adversities, and challenges. It helps to look positively and constructively deal with stressful situations. It is important in the process of raising a conscious young person to live in a society (Xiaodong, 2009). Hardiness is, among others, a predictor of achievements such as success in difficult professions (Kelly et al., 2014), affects school achievements (Vashishtha \& Joshi, 2015), sports achievements (Nezhad \& Besharat, 2010), sanity (Atri et al., 2007), well-being (Nayyeri \& Aubi, 2011) and prevents addiction tendencies (Soleimani et al., 2016). Sailing people often want to transfer their passion to their family, because they believe that it is good and developing for them (Romaniuk \& Łukasiewicz-Wieleba, 2020). These qualities are needed by modern youth, so it is worth forming them through sail training, whose unique advantage is that it takes place on a ship that crew cannot abandon, so all problems must be solved, weaknesses must be overwhelmed, obstacles must be overcome, and difficulties can be defeated.

\section{References:}

Allred, K.D., \& Smith, T.W. (1989). The Hardy Personality: Cognitive and Physiological Responses to Evaluative Threat. Journal of Personality and Social Psychology, 56(2), pp. 257-266.

Atri, A., Sharma, M., \& Cottrell, R. (2007). Role of Social Support, Hardiness, and Acculturation as Predictors of Mental Health Among International Students of Asian Indian Origin. International Quarterly of Community Health Education, 27(1), pp. 59-73, doi: 10.2190\%2FIQ.27.1.e.

Bandura, A., \& Walters, R.H. (1977). Social Learning Theory. Vol. 1. Englewood Cliffs, NJ: Prentice-Hall.

Bartone, P.T. (2012). Psychological Hardiness and Coping Style as Risk/Resilience Factors for Alcohol Abuse. Military Medicine, 177, 500-517, doi: 10.7205/MILMED-D-11-00200.

Bartone, P.T., Ursano, R.J., Wright, K.M., \& Ingraham, L.H. (1989). The Impact of a Military Air Disaster on the Health of Assistance Workers. Journal of Nervous And Mental Disease, 177(6), 317-328.

Heller, K.A., Mönks, F.J., Sternberg, R.J., \& Subotnik, R.F. (2000). International Handbook of Giftedness and Talent. Elsevier Science Ltd. 
Kelly, D.R., Matthews, M.D., \& Bartone, P.T. (2014). Grit and Hardiness as Predictors of Performance Among West Point Cadets. Military Psychology, 26(4), 327-342, doi: 10.1037/mil0000050.

Khalatbari, J., Ghorbanshirodi, S., \& Akhshabi, M. (2013). The Relationship Between Hardiness and Exam Anxiety in Students. Life Science Journal, 10, 185-188.

Kobasa, S. (1979). Stressful Life Events, Personality and Health: An Inquiry Into Hardiness. Journal of Personality and Social Psychology, 37 (1), 1-11, doi: 10.1037/00223514.37.1.1.

Kobasa, S.C., Maddi, S.R., \& Kahn, S. (1982). Hardiness and Health: a Prospective Study. Journal of Personality and Social Psychology, 42 (1), 168-177, doi: 10.1037/00223514.42.1.168.

Kozielecki, J. (1986). A Transgressive Model of Man. New Ideas in Psychology, 4(1), 89105, doi: 10.1016/0732-118X(86)90062-0.

Kozielecki, J. (1987). The Role of Hubristic Motivation in Transgressive Behavior. New Ideas in Psychology, 5(3), 361-383, doi: 10.1016/0732-118X(87)90006-7.

Maddi, S.R. (1999). The Personality Construct of Hardiness: I. Effects on Experiencing, Coping, and Strain. Consulting Psychology Journal: Practice and Research, 51(2), 83-94, 10.1037/1061-4087.51.2.83.

Maddi, S.R. (2002). The Story of Hardiness: Twenty Years of Theorizing, Research, and Practice. Consulting Psychology Journal, 54, 173-185, doi: 10.1037/1061-4087.54.3.173.

Maddi, S.R. (2006). Hardiness: The Courage to Grow From Stresses. The Journal of Positive Psychology, 1(3), 160-168, doi: 10.1080/17439760600619609.

Maddi, S.R., \& Hess, M.J. (1992). Personality Hardiness and Success in Basketball. International Journal of Sport Psychology, 23(4), 360-368.

Maddi, S.R., \& Khoshaba, D.M. (2003). Hardiness Training for Resiliency and Leadership. In: D. Paton, J.M. Violanti, \& L.M. Smith (Eds.), Promoting Capabilities to Manage Posttraumatic Stress: Perspectives on Resilience (pp. 43-58). Springfield, Illinois: Charles C. Thomas Publisher, Ltd.

Maddi, S.R., Harvey, R.H., Khoshaba, D.M., Fazel, M., \& Resurreccion, N. (2009). The Personality Construct of Hardiness, IV: Expressed in Positive Cognitions and Emotions Concerning Oneself and Developmentally Relevant Activities. Journal of Humanistic Psychology, 49(3), 292-305, doi: 10.1177\%2F0022167809331860.

Maddi, S.R., Harvey, R.H., Khoshaba, D.M., Lu, J.L., Persico, M., \& Brow, M. (2006). The Personality Construct of Hardiness, III: Relationships with Repression, Innovativeness, Authoritarianism, and Performance. Journal of Personality, 74(2), 575-598. 
Maddi, S.R., Khoshaba, D.M., Harvey, R.H., Fazel, M., \& Resurreccion, N. (2011). The Personality Construct of Hardiness, V: Relationships with the Construction of Existential Meaning in Life. Journal of Humanistic Psychology, 51(3), 369-388, doi: $10.1177 \% 2 \mathrm{~F} 0022167810388941$.

Maddi, S.R., Khoshaba, D.M., Persico, M., Lu, J., Harvey, R., \& Bleecker, F. (2002). The Personality Construct of Hardiness: II. Relationships with Comprehensive Tests of Personality and Psychopathology. Journal of Research in Personality, 36(1), 72-85, doi: 10.1006/jrpe.2001.2337.

Magnani, L.E. (1990). Hardiness, Self-Perceived Health, and Activity Among Independently Functioning Older Adults. Scholarly Inquiry for Nursing Practice, 4(3), 171-188.

Mostafei, A. (2012). An Investigation of Relationship Between Hardiness and Mental Disorders of Payame-Noor University Students. Annals of Biological Research, 3(2), 1153-1156.

Nathawat, S.S., Desai, M., \& Majumdar, B. (2010). Hardiness as Predictor of Mental Health in Woman Executives. 11th International Conference on HRD Research and Practice across Europe. Pecs, Hungary: University Forum for Human Resource Development.

Nayyeri, M., \& Aubi, S. (2011). Prediction Well-Being on Basic Components of Hardiness. Procedia-Social and Behavioral Sciences, 30, 1571-1575, doi: 10.1016/j. sbspro.2011.10.305.

Nezhad, M.A., \& Besharat, M.A. (2010). Relations of Resilience and Hardiness with Sport Achievement and Mental Health in a Sample of Athletes. Procedia-Social and Behavioral Sciences, 5, 757-763, doi: 10.1016/j.sbspro.2010.07.180.

Pollock, S.E. (1989). The Hardiness Characteristic: A Motivating Factor in Adaptation. Advances in Nursing Science, 11(2), 53-62, doi: 10.1097/00012272-198901000-00009.

Renzulli, J. (1977). Enrichment Triad Model. Wetherfield: Creative Learning Press.

Romaniuk, M.W. (2015). Człowiek w konfrontacji z żywiołem - sytuacje graniczne na morzu [The Man in Confrontation with the Elements - Limit Situations at the Sea]. In: S. Jaronowska (Ed.), Człowiek w sytuacji granicznej. Filozoficzne, kulturowe i historyczne wymiary refleksji i jej implikacje pedagogiczne [The Man in Limit Situation. Philosophical, Cultural and Historical Dimensions of Reflection and its Pedagogical Implications], (pp. 360-368). Warszawa: Wydawnictwo Akademii Pedagogiki Specjalnej.

Romaniuk, M.W. (2018). Mariusz Zaruski jako prekursor wychowania morskiego w Polsce [Mariusz Zaruski as a Precursor of Sail Training in Poland]. Problemy Opiekuńczo-Wychowawcze, 574(9), 3-13.

Romaniuk, M.W., \& Łukasiewicz-Wieleba, J. (2019). Żeglarstwo morskie w oczach młodzieży - wyobrażenia, obawy i oczekiwania [Sailing The Seas As Perceived By Youth - Images, Fears And Expectations]. Edukacja, 4(151), 123-138. 
Romaniuk, M.W., \& Łukasiewicz-Wieleba, J. (2020). Pasja żeglarstwa jako element transferu międzypokoleniowego [The Passion For Sailing As An Element Of Intergenerational Transfer]. Kultura I Edukacja, 1(127), 180-194.

Romaniuk, M.W. (2020a). Nieprzeciętna młodzież a edukacja nieformalna w praktyce - poczucie własnej skuteczności młodych uczestników pełnomorskich rejsów a różne realizacje Szkoły pod Żaglami [Extraordinary Youth and Informal Education in Practice - Self-Efficacy of Young High Sea Cruises Participants and Various Implementations of School Under Sails]. In: B. Cieśleńska, \& E. Wiśniewska (Eds.), Uczeń ze specjalnymi potrzebami edukacyjnymi $w$ teorii i praktyce szkolnej [A Student with Special Educational Needs in School Theory and Practice], (pp. 393-408). Płock: Wydawnictwo Naukowe Mazowiecka Uczelnia Publiczna w Płocku.

Romaniuk, M.W. (2020b). Samoocena młodych uczestników pełnomorskich rejsów a różne realizacje Szkoły pod Żaglami [Self-Esteem of Young High Sea Cruises Participants and Various Implementations of School Under Sails]. Kwartalnik Pedagogiczny, 65(2(256)), 177-189; doi: 10.31338/2657-6007.kp.2020-2.10.

Romaniuk, M.W. (2020c). Wychowanie morskie i jego miejsce wśród koncepcji pedagogicznych [Sail Training and its Place Among Pedagogical Concepts]. Problemy Opiekuńczo-Wychowawcze, 590(5), 3-16.

Romanowska-Tołłoczko, A., \& Piwowarczyk, P. (2015). The Assessment of Difficulty of Yacht Sailing Classes and Students' Global Self-Esteem. Physical Education of Students, 3, 79-83.

Sajadi, S., Kiakojouri, D., \& Hatami, G. (2012). The Relationship Between Anxiety and Difficulties in Emotion Regulation with General Health and Psychological Hardiness in Students of Islamic Azad University. Indian Journal of Fundamental and Applied Life Sciences, 2 (3), 117-125.

Shchipanova, D.Y., Tserkovnikova, N.G., Uskova, B.A., Puzyrev, V.V., Markova, A. S., \& Fomin, E.P. (2016). Hardiness of Adolescents with Special Educational Needs: Research Results. International Journal of Environmental and Science Education, 11 (17), 9829-9838.

Soleimani, M.A., Sharif, S.P., Yaghoobzadeh, A., \& Ong, F.S. (2016). Relationship Between Hardiness and Addiction Potential in Medical Students. Iranian Journal of Psychiatry and Behavioral Sciences, 10 (4):e622, doi: 10.17795/ijpbs-6225.

Vashishtha, K., \& Joshi, U. (2015). Impact of Hardiness on Academic Performance of College Students. Journal for Studies in Management and Planning, 1(2), 143-148.

Xiaodong, Y.U. (2009). Youth Dispositional Empowerment: Cultivating Hardiness and Resilience. In: E.S. Liu, M.J. Holosko, \& W.T. Lo (Eds.), Youth Empowerment and Volunteerism: Principles, Policies and Practices (pp. 83-106). Hong Kong: City University of Hong Kong Press. 